\title{
Validation by experts of Risk of suicide Nursing Diagnosis in the elderly
}

\author{
Validação por especialistas do Diagnóstico de Enfermagem Risco de suicídio em idosos \\ Validación por especialistas del Diagnóstico de Enfermería Riesgo de suicidio en ancianos
}

\section{Girliani Silva de Sousa' \\ ORCID: 0000-0002-0988-5744 \\ Jaqueline Galdino Albuquerque Perrelli" \\ ORCID: 0000-0003-4934-1335 \\ Suzana de Oliveira Mangueira" ORCID: 0000-0003-0931-8675 \\ Everton Botelho Sougey' ORCID: 0000-0003-0125-9201}

'Universidade Federal de Pernambuco. Recife, Pernambuco, Brazil.

"Universidade Federal de Pernambuco.

Vitória de Santo Antão, Pernambuco, Brazil.

How to cite this article:

Sousa GS, Perrelli JGA, Mangueira SO, Sougey EB.

Validation by experts of Risk of suicide Nursing Diagnosis in the elderly. Rev Bras Enferm. 2019;72(Suppl 2):111-8. doi: http://dx.doi.org/10.1590/0034-7167-2018-0252

\section{Corresponding Author:}

Girliani Silva de Sousa

E-mail: girlianis@gmail.com

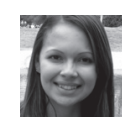

Submission: 05-09-2018

Approval: 06-10-2019

\begin{abstract}
Objective: to validate the conceptual and operational definitions content of factors for Risk of suicide Nursing Diagnosis in the elderly. Method: this is validation of the conceptual and operational definitions content of factors for Risk of suicide in the elderly, performed by 15 experts, from November 2015 to March 2016. Risk factors were classified into three hierarchical chuncks. The data were analyzed by descriptive statistics and binomial test. Results: of the 54 validated risk factors, only eight presented problems regarding clarity, simplicity and accuracy: chronic pain, vision problems, retirement, frustration, medication neglect and depression. Only rigidity was not validated as relevant for the study diagnosis. Conclusion: content validation of the risk factors for Nursing Diagnosis can guide the clinical practice of the nurse in the early detection of risk of suicide in the elderly.

Descriptors: Nursing Diagnostic; Aged: Validation Studies; Risk Factors; Suicide.
\end{abstract}

\section{RESUMO}

Objetivo: validar o conteúdo das definições conceituais e operacionais dos fatores do Diagnóstico de Enfermagem Risco de suicídio em idosos. Método: trata-se de validação de conteúdo das definições conceituais e operacionais dos fatores do Diagnóstico de Enfermagem Risco de suicídio em idosos, realizada por 15 especialistas, no período de novembro de 2015 a março de 2016. Os fatores de risco foram classificados em três blocos hierarquizados. Os dados foram analisados por meio de estatística descritiva e teste binomial. Resultados: dos 54 fatores de risco validados, apenas oito apresentaram problemas quanto à clareza, simplicidade e precisão: dor crônica, problemas visuais, aposentadoria, frustração, descuido com a medicação e depressão. Apenas rigidez não foi validada como relevante para o diagnóstico em estudo. Conclusão: a validação de conteúdo dos fatores de risco do Diagnóstico de Enfermagem pode nortear a prática clínica do enfermeiro na detecção precoce do risco de suicídio em idosos.

Descritores: Diagnóstico de Enfermagem; Idoso; Estudos de Validação; Fatores de Risco; Suicídio.

\section{RESUMEN}

Objetivo: validar el contenido de las definiciones conceptuales y operacionales de los factores del Diagnóstico de Enfermería Riesgo de suicidio en ancianos. Método: estudio de validación de contenido de las definiciones conceptuales y operativas de los factores del diagnóstico de enfermería Riesgo de suicidio en ancianos, por 15 especialistas, en noviembre de 2015 a marzo de 2016. Los factores de riesgo se clasificaron en tres bloques jerárquicos. Los datos fueron analizados por medio de estadística descriptiva y prueba binomial. Resultados: de los 54 factores de riesgo validados, ocho presentaron problemas en la claridad, simplicidad y precisión: dolor crónico, problemas visuales, jubilación, frustración, descuido con la medicación y depresión. Sólo la rigidez no fue validada como relevante para el diagnóstico. Conclusión: la validación de contenido de los factores de riesgo del diagnóstico de enfermería puede orientar la práctica clínica del enfermero en la detección precoz del riesgo de suicidio en ancianos. Descriptores: Diagnóstico de Enfermería; Ancianos; Estudios de Validación; Fatores de Riesgo; Suicídio. 


\section{INTRODUCTION}

Suicide represents a positive or negative act perpetrated by the victim who, directly or indirectly, will end with his life ${ }^{(1)}$. Indeed, for attempted suicide, it is assumed that the self-destructive act was unable to result in death. This phenomenon is worrisome worldwide due to the psychological, social, economic and cultural impacts on the family and society ${ }^{(2)}$.

Suicide is the most relevant cause of violent death among elderly people. According to the World Health Organization (WHO), suicide is among the top ten causes of death in the world. In order to be aware of the magnitude of the problem, 804 thousand people take their own lives a year, which represents an annual rate of $11.4 / 100,000$ inhabitants, of which 15/100,000 are men and 8.0 / 100,000 are women ${ }^{(2)}$. There is an increase in rates between men and women over 70 years of age in different regions of the world, with the exception of some African and Asian countries where youth and young adult groups lead statistics ${ }^{(2)}$.

In Brazil, in 2015, there was a significant increase in suicide deaths compared to previous years, with an annual suicide rate of 5.7/100,000 inhabitants. Among the elderly, suicide mortality is more prevalent in the age group over 70 years, reaching $8.9 / 100,000$ inhabitants $^{(3)}$.

The WHO points out that for each suicide there are more than 20 people who try it without success ${ }^{(4)}$. This proportion is lower among the elderly, since for every two or three suicide attempts a death occurs ${ }^{(5)}$. This shows that the existence of a prior attempt is one of the most relevant risk factors for suicide.

Data from the Brazilian Institute of Geography and Statistics (IBGE - Instituto Brasileiro de Geografia e Estatística) show the accelerated growth of the elderly population. Estimates for 2030 estimate that there will be 40.5 million elderly people in Brazil, corresponding to $18.7 \%$ of the population. Moreover, in 2050 it is estimated that this age group will account for about $29 \%$ of the total Brazilian population ${ }^{(6)}$.

In addition to the epidemiological dimension, the social and anthropological sense of ageing closely approximates the risk of suicide. They are elderly people who lose hope of having an easier and more dignified future and find in their silence, apathy, discouragement, sadness, social isolation and solitude ways of dealing with suffering in the face of functional incapacity, lack of care and the absence of a social support network ${ }^{(7)}$. In this context, ageing represents a challenge for the Brazilian reality, given the different perceptions about old age and the increasing increase of suicide rates in this age group.

In this perspective, nurses play a crucial role in welcoming and caring to elderly people at risk of suicide, and should adopt tools that support clinical reasoning and decision making, among which are the use of Nursing Diagnosis (ND) taxonomies. In this context, the NANDA International (NANDA-I) Risk of suicide phenomenon stands out and is defined as "vulnerability to self-inflicted lifethreatening injury". This ND is located in domain 11 - security/ protection, in class 3 - violence and consists of 47 risk factors ${ }^{(8)}$. The aforementioned diagnosis was reviewed by researchers in a previous step to this research ${ }^{(9)}$, which incorporated the 23 new risk factors for ND below: apathy; agitation; low self-esteem; carelessness with medication; inability to ask for help; inability to express feelings; suicide plan; rigidity; functional disability; vision problems; sadness; hostility; anxiety; failure; frustration; unhappiness; dishonor; frequent visits to a physician with vague symptoms; social deprivation; social devaluation; psychological violence; intrafamily violence; and financial violence.

However, the conceptual and operational definitions ND risk factors content was not submitted to expert analysis. For this reason, it is proposed, through the validation of content by experts, that, through scientific evidence, the probability of errors in the diagnostic process is reduced, and with this, nursing interventions that are consistent with the real needs of individuals.

In this sense, the results of this study may contribute to the Ministry of Health's efforts to reduce the absolute number of suicides by $10.0 \%$ in the country by $2020^{(3)}$, by producing knowledge that will permeate the qualification of nurses' practices in suicide prevention.

\section{OBJECTIVE}

To validate the conceptual and operational definitions content of the factors for Risk of suicide ND in the elderly.

\section{METHOD}

\section{Ethical aspects}

The project was approved by the Research Ethics Committee of the Health Sciences Center of the Universidade Federal de Pernambuco. All ethical aspects of Resolution 466/12 of the Brazilian National Health Board (Conselho Nacional de Saúde). Confidentiality of the information and the right of withdrawal were ensured at any time without prejudice to the integrity of the participants.

\section{Design, study place and period}

It is a research of the methodological type ${ }^{(10)}$, developed from November 2015 to March 2016, whose focus was to validate the conceptual and operational definitions content elaborated for the risk factors of said diagnosis, from a integrative review ${ }^{(9)}$. Risk factors were classified according to the "Integrated MotivationalVolitional Model of Suicidal Behavior" theoretical framework ${ }^{(11)}$. The definitions were assessed according to the criteria of clarity, relevance, accuracy and simplicity recommended by Psychometrics $^{(12)}$ for the elaboration of constitutive and operational definitions.

The Integrated Motivational-Volitional Model of Suicidal Behavior considers suicide as a behavioral process and divides it into three phases: pre-motivational (which involves the biological sensitivity of the individual to life experiences, aspects of formation of their behavioral repertoire), motivational (involves a series of complex psychological processes in the formation of suicidal ideations) and the volitional (examines the transition from suicidal ideation to suicide attempts) ${ }^{(11)}$.

\section{Sample, inclusion and exclusion criteria}

At this stage, identification and selection of experts occurred. The sample was intentional and non-probabilistic. Nurses were located through the Lattes platform (Plataforma Lattes) of the National Council of Scientific and Technological Development (CNPq-Conselho Nacional de Desenvolvimento Científico e Tecnológico) from the following keywords: 
nursing diagnoses, suicide and elderly/ageing. Moreover, experts selection was carried out by snowball sampling in which reference chains were used, so that when an individual who met the inclusion criteria was located, it was asked to indicate other participants ${ }^{(13)}$.

Sample calculation of experts followed the recommendations of Lopes, Silva and Araújo ${ }^{(10)}$, based on the following formula:

$$
n=\frac{Z_{1-a / 2} \cdot P \cdot(1-P)}{e^{2}}
$$

The following parameters were adopted: $Z_{1-\alpha / 2}=1,961.96(95 \%$ confidence level), expert agreement ratio of $90.0 \%$ and sampling error of $15.0 \%$. The calculation resulted in 15 participants.

For experts selection, the model proposed by Fehring was composed of seven items, with a minimum score of six and a maximum score of 14 points. This model includes clinical experience, research and teaching of nurses in the area of study interest ${ }^{(14)}$.

Fehring's criteria were adapted to the area and nature of this study, and included the following requirements: a) to be a nurse; b) Master's degree in nursing: four points; c) dissertation directed to relevant contents of the ND under study: one point; $d$ ) published researches on taxonomies of nursing and with content relevant to the study: a point; e) publication of an article in an indexed journal involving nursing taxonomies with themes relevant to the study area: two points; f) doctoral degree in nursing with thesis in the area of study interest: two points; $g$ ) clinical experience of at least one year in the diagnostic area under study: two points; h) certification of specialization or residency in the clinical area relevant to the topic addressed: two points. It is observed, therefore, that there was no change in the score attributed by Fehring to each item of the scale.

From the established criteria, the nurse should obtain the minimum score of six points to be considered expert. Those who did not return the instrument duly completed within 30 days were excluded.

The search on the Lattes platform resulted in 77 potential experts. After initial contact and sending of the invitation letter by email, 38 (49\%) did not respond, 15 (19\%) refused and 24 (31\%) accepted to participate in the study. Of these, 15 (62.5\%) experts composed the study sample and nine were excluded because they did not return the instrument within the established period.

\section{Study protocol}

The experts received by e-mail a protocol composed of two instruments: the first one referring to the socio-demographic and academic characterization and the second one composed by a table with the 54 risk factors for the suicide of the elderly ${ }^{(9)}$ and their conceptual and operational definitions to be assessed according to the criteria recommended by Psychometrics ${ }^{(12)}$. Each criterion was assessed using a three-point scale ( 2 = adequate, 1 $=$ not adequate and $0=$ inadequate). In addition, a blank space was destined in the instrument so that the experts could register suggestions, criticisms or observations pertinent to the subject.

The protocol also had guidelines regarding the fulfillment of the instruments, deadlines for the delivery of the material, as well as the ethical aspects of the study and the Free and Informed Consent Term (FICT).

Risk of suicide ND risk factors in the elderly were classified into three hierarchical chuncks ${ }^{(11)}$ :
Chunck 1 or distal level (variables in relation to life events and behavioral aspects of the individual): alcohol abuse; child abuse; abandonment; agitation; anxiety; retirement; family conflict; fault; dishonor; divorce; chronic-degenerative diseases; terminal diseases; chronic pain; frequent visits to the doctor with vague symptoms; hostility; inability to ask for help; inability to express feelings; live alone; loss of significant relationship; social deprivation; financial problems; vision problems; rigidity; financial, physical, psychological or intrafamily violence; widowhood.

Chunck 2 or intermediate level (variables of complex psychological processes that will form the suicidal ideation): apathy; insufficient social support; low self-esteem; low autonomy; functional dependence; hopelessness; social devaluation; failure; frustration; unhappiness; functional incapacity; social isolation; make a testament; ill-fated grieving; significant change of behavior; loneliness; sadness.

Chunck 3 or proximal level (variables that incorporate the transformation of ideation into a suicide attempt): self-neglect; medication storage; depression; carelessness with medication; suicide attempt history; suicidal ideation; suicide plan; sudden recovery from deep depression and mental disorder.

\section{Analysis of results, and statistics}

The data were organized in an Excel 2007 spreadsheet and analyzed using the statistical package SPSS, version 17.0. The characterization of the sample was performed by means of descriptive statistics. The experts' answers were dichotomized in adequate (1) and inadequate (0) for items that were considered inadequate and inadequate. The percentages of adequacy of the conceptual and operational definitions were calculated. Moreover, the binomial test was applied in order to verify if the proportion of experts who considered the appropriate item was greater or equal to the pre-established value of $90.0 \%$. In this case, the item was considered adequate if the $p$ value for the binomial test was greater than or equal to 0.05 ( $p>0.05$ ). The relevance criterion was decisive for considering the validated definitions.

\section{RESULTS}

The sample consisted of 15 expert nurses, with a mean age of 44.60 years $( \pm 10.6)$. Four experts (20.0\%) came from Minas Gerais State (MG), three (20.0\%) from Ceará State (CE), two (13.3\%) from Santa Catarina State (SC) and two (13.3\%) from Rio Grande do Sul State (RS).

Regarding the criteria adapted from the Fehring model ${ }^{(14)}$ for the selection of experts, the nurses averaged 9.60 points ( \pm 2.32). All participants had a doctoral degree. The mean training time was 22 years ( \pm 10.4$)$. The majority $(93.3 \%)$ have a master's degree in nursing and one $(7.1 \%)$ in gerontology.

Three participants (20\%) are experts in Mental Health, two (13.3\%) in Geriatrics, two (13.3\%) in Public/Collective Health and the others in other related fields. Twelve (80\%) work as teachers in Public Higher Education Institutions. Nursing Process was used by all participants, whether in teaching or care practice. Of these, $60.0 \%$ had clinical experience in nursing care for the elderly with suicidal behavior.

The experts assertively made suggestions for textual adaptations, such as revision of long sentences and changes in nomenclature of 
risk factors with the objective of making them clearer and more precise to be incorporated and assessed in gerontological nursing care.

Regarding content analysis of the conceptual and operational definitions, after using the binomial test, it was evidenced that $24(85.7 \%)$ distal level risk factors (chunck 1) were considered adequate and significantly validated among experts for Risk of suicide. Exception occurred between the rigidity, chronic pain, vision problems and retirement factors, as shown in Table 1.

Regarding the intermediate level factors (chunck 2), all were adequate for Risk of suicide ( $p<0.05$ ), except for the frustration factor that presented fragility in its conceptual definition, regarding clarity $(p=0.013)$. Further information is in Table 2.

Table 1 - Analysis by experts of the conceptual and operational definitions of distal level factors for Risk of suicide, Recife, Pernambuco, Brazil, 2016

\begin{tabular}{|c|c|c|c|c|c|c|c|c|c|c|c|c|}
\hline \multirow{3}{*}{ Risk factors } & \multicolumn{12}{|c|}{ Conceptual definitions } \\
\hline & \multicolumn{3}{|c|}{ Relevance } & \multicolumn{3}{|c|}{ Clarity } & \multicolumn{3}{|c|}{ Accuracy } & \multicolumn{3}{|c|}{ Simplicity } \\
\hline & $\mathbf{n}$ & $\%$ & $p$ value* & $\mathbf{n}$ & $\%$ & $p$ value* & $\mathbf{n}$ & $\%$ & $p$ value* & $\mathbf{n}$ & $\%$ & $p$ value* \\
\hline Rigidity & 10 & 66.7 & 0.013 & 10 & 66.7 & 0.013 & 11 & 73.3 & 0.056 & 10 & 66.7 & 0.013 \\
\hline Chronic pain & 12 & 80.0 & 0.184 & 10 & 66.7 & 0.013 & 10 & 66.7 & 0.013 & 11 & 73.3 & 0.056 \\
\hline Vision problems & 11 & 73.3 & 0.056 & 10 & 66.7 & 0.013 & 10 & 66.7 & 0.013 & 9 & 60.0 & 0.002 \\
\hline \multirow[t]{2}{*}{ Retirement } & 12 & 80.0 & 0.184 & 10 & 66.7 & 0.013 & 10 & 66.7 & 0.013 & 10 & 66.7 & 0.013 \\
\hline & \multicolumn{12}{|c|}{ Operational definitions } \\
\hline Rigidity & 10 & 66.7 & 0.013 & 9 & 60.0 & 0.002 & 10 & 66.7 & 0.013 & 9 & 60.0 & 0.002 \\
\hline Chronic pain & 12 & 80.0 & 0.184 & 10 & 66.7 & 0.013 & 10 & 66.7 & 0.013 & 11 & 73.3 & 0.056 \\
\hline Vision problems & 11 & 73.3 & 0.056 & 9 & 60.0 & 0.002 & 10 & 66.7 & 0.013 & 9 & 60.0 & 0.002 \\
\hline Retirement & 13 & 86.7 & 0.451 & 11 & 73.3 & 0.056 & 10 & 66.7 & 0.013 & 10 & 66.7 & 0.013 \\
\hline
\end{tabular}

Note: *Binomial test.

Table 2 - Analysis by experts of the conceptual and operational definitions of intermediate level factors for Risk of suicide, Recife, Pernambuco, Brazil, 2016

\begin{tabular}{|c|c|c|c|c|c|c|c|c|c|c|c|c|}
\hline \multirow{3}{*}{ Risk factors } & \multicolumn{12}{|c|}{ Conceptual definitions } \\
\hline & \multicolumn{3}{|c|}{ Relevance } & \multicolumn{3}{|c|}{ Clarity } & \multicolumn{3}{|c|}{ Accuracy } & \multicolumn{3}{|c|}{ Simplicity } \\
\hline & $\mathbf{n}$ & $\%$ & $p$ value* & $\mathbf{n}$ & $\%$ & $p$ value* & $\mathbf{n}$ & $\%$ & $p$ value* & $\mathbf{n}$ & $\%$ & $p$ value* \\
\hline Apathy & 14 & 93.3 & 0.794 & 14 & 93.3 & 0.794 & 15 & 100.0 & 1.000 & 14 & 93.3 & 0.794 \\
\hline Insufficient social support & 15 & 100.0 & 1.000 & 14 & 93.3 & 0.794 & 15 & 100.0 & 1.000 & 14 & 93.3 & 0.794 \\
\hline Low self-esteem & 14 & 93.3 & 0.794 & 14 & 93.3 & 0.794 & 14 & 93.3 & 0.794 & 14 & 93.3 & 0.794 \\
\hline Low autonomy & 13 & 86.7 & 0.451 & 12 & 80.0 & 0.184 & 12 & 80.0 & 0.184 & 12 & 80.0 & 0.184 \\
\hline Functional dependence & 13 & 86.7 & 0.451 & 13 & 86.7 & 0.451 & 12 & 80.0 & 0.184 & 13 & 86.7 & 0.451 \\
\hline Hopelessness & 14 & 93.3 & 0.794 & 13 & 86.7 & 0.451 & 13 & 86.7 & 0.451 & 13 & 86.7 & 0.451 \\
\hline Social devaluation & 14 & 93.3 & 0.794 & 14 & 93.3 & 0.794 & 14 & 93.3 & 0.794 & 14 & 93.3 & 0.794 \\
\hline Make a testament & 13 & 86.7 & 0.451 & 14 & 93.3 & 0.794 & 14 & 93.3 & 0.794 & 14 & 93.3 & 0.794 \\
\hline Failure & 13 & 86.7 & 0.451 & 14 & 93.3 & 0.794 & 13 & 86.7 & 0.451 & 14 & 93.3 & 0.794 \\
\hline Frustration & 13 & 86.7 & 0.451 & 10 & 66.7 & 0.013 & 12 & 80.0 & 0.184 & 13 & 86.7 & 0.451 \\
\hline Functional incapacity & 13 & 86.7 & 0.451 & 12 & 80.0 & 0.184 & 13 & 86.7 & 0.451 & 13 & 86.7 & 0.451 \\
\hline Unhappiness & 14 & 93.3 & 0.794 & 14 & 93.3 & 0.794 & 14 & 93.3 & 0.794 & 14 & 93.3 & 0.794 \\
\hline Social isolation & 15 & 100.0 & 1.000 & 15 & 100.0 & 1.000 & 15 & 100.0 & 1.000 & 15 & 100.0 & 1.000 \\
\hline Ill-fated grieving & 14 & 93.3 & 0.794 & 13 & 86.7 & 0.451 & 14 & 93.3 & 0.794 & 13 & 86.7 & 0.451 \\
\hline Significant change of behavior & 12 & 80.0 & 0.184 & 14 & 93.3 & 0.794 & 14 & 93.3 & 0.794 & 15 & 100.0 & 1.000 \\
\hline Loneliness & 15 & 100.0 & 1.000 & 13 & 86.7 & 0.451 & 13 & 86.7 & 0.451 & 13 & 86.7 & 0.451 \\
\hline Sadness & 13 & 86.7 & 0.451 & 13 & 86.7 & 0.451 & 13 & 86.7 & 0.451 & 14 & 93.3 & 0.794 \\
\hline \multicolumn{13}{|c|}{ Operational definitions } \\
\hline Apathy & 13 & 86.7 & 0.451 & 13 & 86.7 & 0.451 & 14 & 93.3 & 0.794 & 12 & 80.0 & 0.184 \\
\hline Insufficient social support & 15 & 100.0 & 1.000 & 14 & 93.3 & 0.794 & 14 & 93.3 & 0.794 & 14 & 93.3 & 0.794 \\
\hline Low self-esteem & 14 & 93.3 & 0.794 & 13 & 86.7 & 0.451 & 13 & 86.7 & 0.451 & 12 & 80.0 & 0.184 \\
\hline Low autonomy & 15 & 100.0 & 1.000 & 15 & 100.0 & 1.000 & 15 & 100.0 & 1.000 & 15 & 100.0 & 1.000 \\
\hline Functional dependence & 14 & 93.3 & 0.794 & 14 & 93.3 & 0.794 & 13 & 86.7 & 0.451 & 14 & 93.3 & 0.794 \\
\hline Hopelessness & 14 & 93.3 & 0.794 & 13 & 86.7 & 0.451 & 13 & 86.7 & 0.451 & 13 & 86.7 & 0.451 \\
\hline Social devaluation & 14 & 93.3 & 0.794 & 13 & 86.7 & 0.451 & 13 & 86.7 & 0.451 & 13 & 86.7 & 0.451 \\
\hline Make a testament & 13 & 86.7 & 0.451 & 14 & 93.3 & 0.794 & 14 & 93.3 & 0.794 & 14 & 93.3 & 0.794 \\
\hline Failure & 14 & 93.3 & 0.794 & 14 & 93.3 & 0.794 & 13 & 86.7 & 0.451 & 14 & 93.3 & 0.794 \\
\hline Frustration & 13 & 86.7 & 0.451 & 12 & 80 & 0.184 & 12 & 80 & 0.184 & 13 & 86.7 & 0.451 \\
\hline Functional incapacity & 13 & 86.7 & 0.451 & 12 & 80 & 0.184 & 12 & 80 & 0.184 & 11 & 73.3 & 0.056 \\
\hline Unhappiness & 15 & 100.0 & 1.000 & 13 & 86.7 & 0.451 & 13 & 86.7 & 0.451 & 13 & 86.7 & 0.451 \\
\hline Social isolation & 15 & 100.0 & 1.000 & 15 & 100.0 & 1.000 & 15 & 100.0 & 1.000 & 15 & 100.0 & 1.000 \\
\hline IIl-fated grieving & 14 & 93.3 & 0.794 & 13 & 86.7 & 0.451 & 13 & 86.7 & 0.451 & 12 & 80.0 & 0.184 \\
\hline Significant change of behavior & 11 & 73.3 & 0.056 & 11 & 73.3 & 0.056 & 11 & 73.3 & 0.056 & 12 & 80.0 & 0.184 \\
\hline Loneliness & 15 & 100.0 & 1.000 & 13 & 86.7 & 0.451 & 13 & 86.7 & 0.451 & 13 & 86.7 & 0.451 \\
\hline Sadness & 13 & 86.7 & 0.451 & 13 & 86.7 & 0.451 & 13 & 86.7 & 0.451 & 14 & 93.3 & 0.794 \\
\hline
\end{tabular}


Table 3 - Experts analysis of the conceptual and operational definitions of proximal level factors for Risk of suicide, Recife, Pernambuco, Brazil, 2017

\begin{tabular}{|c|c|c|c|c|c|c|c|c|c|c|c|c|}
\hline \multirow{3}{*}{ Risk factors } & \multicolumn{12}{|c|}{ Conceptual definitions } \\
\hline & \multicolumn{3}{|c|}{ Relevance } & \multicolumn{3}{|c|}{ Clarity } & \multicolumn{3}{|c|}{ Accuracy } & \multicolumn{3}{|c|}{ Simplicity } \\
\hline & $\mathbf{n}$ & $\%$ & $p$ value* & $\mathbf{n}$ & $\%$ & $p$ value* & $\mathbf{n}$ & $\%$ & $p$ value* & $\mathbf{n}$ & $\%$ & $p$ value* \\
\hline Medication storage & 14 & 93.3 & 0.794 & 15 & 100.0 & 1.000 & 14 & 93.3 & 0.794 & 15 & 100.0 & 1.000 \\
\hline Self-neglect & 14 & 93.3 & 0.794 & 14 & 93.3 & 0.794 & 14 & 93.3 & 0.794 & 14 & 93.3 & 0.794 \\
\hline Carelessness with medication & 12 & 80.0 & 0.184 & 12 & 80.0 & 0.184 & 13 & 86.7 & 0.451 & 14 & 93.3 & 0.794 \\
\hline Depression & 12 & 80.0 & 0.184 & 14 & 73.3 & 0.056 & 11 & 73.3 & 0.056 & 12 & 80.0 & 0.184 \\
\hline Suicide attempt history & 14 & 93.3 & 0.794 & 14 & 93.3 & 0.794 & 13 & 86.7 & 0.451 & 15 & 100.0 & 1.000 \\
\hline Suicidal ideation & 15 & 100.0 & 1.000 & 15 & 100.0 & 1.000 & 15 & 100.0 & 1.000 & 15 & 100.0 & 1.000 \\
\hline Suicide plan & 15 & 100.0 & 1.000 & 14 & 93.3 & 0.794 & 15 & 100.0 & 1.000 & 15 & 100.0 & 1.000 \\
\hline Sudden recovery from deep depression & 14 & 93.3 & 0.794 & 13 & 86.7 & 0.451 & 13 & 86.7 & 0.451 & 14 & 93.3 & 0.794 \\
\hline \multirow[t]{2}{*}{ Mental disorders } & 15 & 100.0 & 1.000 & 14 & 93.3 & 0.794 & 14 & 93.3 & 0.794 & 14 & 93.3 & 0.794 \\
\hline & \multicolumn{12}{|c|}{ Operational definitions } \\
\hline Medication storage & 14 & 93.3 & 0.794 & 14 & 93.3 & 0.794 & 13 & 86.7 & 0.451 & 15 & 100.0 & 1.000 \\
\hline Self-neglect & 14 & 93.3 & 0.794 & 13 & 86.7 & 0.451 & 13 & 86.7 & 0.451 & 13 & 86.7 & 0.451 \\
\hline Carelessness with medication & 12 & 80.0 & 0.184 & 10 & 66.7 & 0.013 & 11 & 73.3 & 0.056 & 13 & 86.7 & 0.451 \\
\hline Depression & 14 & 93.3 & 0.794 & 10 & 66.7 & 0.013 & 11 & 73.3 & 0.056 & 11 & 73.3 & 0.056 \\
\hline Suicide attempt history & 15 & 100.0 & 1.000 & 14 & 93.3 & 0.794 & 14 & 93.3 & 0.794 & 15 & 100.0 & 1.000 \\
\hline Suicidal ideation & 15 & 100.0 & 1.000 & 13 & 86.7 & 0.451 & 13 & 86.7 & 0.451 & 13 & 86.7 & 0.451 \\
\hline Suicide plan & 14 & 93.3 & 0.794 & 11 & 73.3 & 0.056 & 12 & 80.0 & 0.184 & 13 & 86.7 & 0.451 \\
\hline Sudden recovery from deep depression & 14 & 93.3 & 0.794 & 13 & 86.7 & 0.451 & 13 & 86.7 & 0.451 & 14 & 93.3 & 0.794 \\
\hline Mental disorders & 15 & 100.0 & 1.000 & 14 & 93.3 & 0.794 & 14 & 93.3 & 0.794 & 14 & 93.3 & 0.794 \\
\hline
\end{tabular}

Note: *Binomial test.

The results showed that seven $(77.0 \%)$ risk factors at the proximal level (chunck 3) had a significant assessment among the experts. Experts pointed out problems regarding the clarity of the operational definitions of carelessness with medication and depression ( $p=$ 0.013 ) risk factors. Table 3 shows the detailed results of this analysis.

\section{DISCUSSION}

For nurses to assess the risks of suicide in the elderly, it is necessary to identify in the nursing consultation the distal level risk factors and behavioral events present throughout the life of this population.

The experts suggested a change in the label and grammatical adequacy in the conceptual and operational definition of the risk factor of child abuse for the history of childhood violence, with the justification that the term child abuse would be nonspecific for nurses to assess the occurrence of physical, domestic violence and sexual intercourse in the elderly's childhood.

In this sense, the identification of childhood violence history can track psychic suffering for Risk of suicide, as evidenced in studies conducted in Norway ${ }^{(15)}$ and Brazil, with elderly people who attempted suicide ${ }^{(16-18)}$, whose results showed that these individuals have had their lives marked since childhood by abuse, violence and other stressful events such as early death of parents and financial difficulties. In turn, the elderly who attempted suicide had more experiences of loss and death in life, whether by divorce, widowhood or significant loss of relationship ${ }^{(16-20)}$.

Other risk factors of the distal level correspond to the social aspects of the life of the elderly. An ecological study conducted in 23 countries in Europe on social support and suicide in the elderly ${ }^{(20)}$ has shown that abandonment, social deprivation, family conflicts and living only for lack of choice are significant risk factors for the reduction of the desire to live. In Australia ${ }^{(21)}$, a case-control study also pointed out that living alone is the most relevant predictor among the elderly who attempted suicide. These subjects present a particular reading of their lives and confirm that the fact of ageing by itself undermines the processes of socialization, as if the invisibility of white hair in society was the ultimate destination of these people.

With regard to the elderly victims of violence, a study carried out in three Brazilian municipalities identified a prevailing age of 60 to 69 years, mostly women and married ${ }^{(22)}$. Psychological violence predominated in reports of violence, then physical, and in the two municipalities of the Northeast, the financial violence ${ }^{(22)}$. These findings corroborate with studies on the elderly who attempted suicide ${ }^{(16-18)}$ and are significant because they identify in low-income populations, where the elderly receive social benefits, there is a greater risk of suffering this kind of violence ${ }^{(22)}$.

Still on distal level risk factors, only retirement, chronic pain, vision problems and rigidity presented problems in the validation. Experts argued that the conceptual definition of the retirement factor generated multiple interpretations and was excessively negative. After reformulations, according to the experts'suggestions, retirement remained a risk factor for Risk of suicide.

The experts considered the chronic pain factor as non-specific in time, thus, it would be difficult to relate it to Risk of suicide in the elderly. Thus, the minimum time of six months to consider chronic pain was adopted. This phenomenon is capable of increasing the vulnerability to depressive symptoms and, consequently, the risk for suicide ${ }^{(20,23)}$.

In addition, it is necessary to investigate the presence of ruminant behavioral processes in relation to chronic-generative diseases. Research on the relationship between such pathologies 
and the suicide of the elderly in the US ${ }^{(23)}$ confirmed that presenting a diagnosis of serious diseases, perception of increased health status and frequent hospitalizations constitute a group at higher risk of suicide. Therefore, among elderly people with cancer, there is greater vulnerability to the desire to die due to physical and mental disorder ${ }^{(24)}$. In China ${ }^{(25)}$, a qualitative study with 32 individuals with stomach cancer found that positive coping, union and family support strategies and the desire to live are protective factors for the risk of suicide.

The vision problems risk factor was reformulated so that the operational definition could scale the vision problems as a consequence of the decline of the physiological system. This resulted in the fragility of the elderly and the lower quality of life, given the intrinsic relationship between vision problems and limitations in performing basic and instrumental activities of daily living among older people. In fact, vision problems can lead to loss of autonomy, resulting in feelings of shame, low self-esteem, and negative thoughts ${ }^{(20-23)}$.

Rigidity was excluded as a risk factor for not presenting relevance for Risk of suicide ND in the elderly. Three experts argued that this aspect would be implicit in a significant change of behavior and that there would be difficulty in tracing it, since, due to its subjectivity, it is difficult for the elderly to verbalize this behavioral trait.

Regarding validated risk factors at the intermediate level, three experts presented difficulties in differentiating frustration and failure and reported that they understood these two phenomena as similar. However, this investigation considers that frustration and failure are distinct risk factors and remain separate in the study ND. Failure corresponds to the state or condition of not achieving a desired goal and may or may not be accompanied by frustration which is an emotional state arising from an unfulfilled expectation ${ }^{(26-27)}$. People with suicidal behavior have neuronal changes that reduce motivational control of responding to outgoing negative encouragement ${ }^{(27)}$, as dependence and functional incapacity; autonomy loss; ill-fated grieving and insufficient social support ${ }^{(16,19-20,26)}$. In these cases, there is a low problem solving ability due to the difficulty making decisions, so that the person has the perception that there is no escape from an aversive situation ${ }^{(28-30)}$.

Other validated intermediate level factors (apathy; insufficient social support; low self-esteem; low autonomy; functional dependence; hopelessness; social devaluation; unhappiness; functional incapacity; social isolation; make a testament; ill-fated grieving; significant change of behavior; loneliness; sadness) confirm the finding by Harrison et al. $^{(26)}$ and Šedivya ${ }^{(20)}$ that the presence of insufficient social support is associated with higher levels of chronic interpersonal difficulties manifested by feelings of apathy, low self-esteem, and hopelessness in the elderly who tried suicide in the US and Europe.

The Integrated Motivational-Volitional Model of Suicidal Behavior $^{(11)}$, when considering suicide as a behavioral process, corroborates the findings of studies that reveal that insufficient social support leads to low self-esteem, self-deprecation with feelings of unhappiness, failure, frustration, unhappiness and sadness $^{(9,15-21,26)}$. From this perspective, it is concluded that for the psychological well-being of the elderly, it is necessary that their psychobiological and self-actualization needs be met ${ }^{(26)}$.

Cognitive inflexibility may increase vulnerability to suicidal thinking, since it is associated with rumination and hopelessness ${ }^{(30)}$.
Rumination can be understood as one of the ways to react to stressful events ${ }^{(31)}$. People with ideation or suicide attempt tend to direct their attention on their negative mood, with repetitive thoughts and negative character about themselves ${ }^{(18-20,30,32)}$. These people present psychosocial maladjustments manifested by apathy, anxiety, low self-esteem, unhappiness, sadness, and hopelessness.

Hopelessness increases the severity of suicidal ideation ${ }^{(21,32-33)}$. A sense of responsibility for the family can make older people feel more burdened and, mediated by their lack of hope for a better life, find recurring and growing thoughts about suicide a way to bring relief to the family ${ }^{(33)}$.

All factors at the proximal level (self-neglect, medication storage, depression, carelessness with medication, history of attempted suicide, suicidal ideation, suicide plan; sudden recovery in relation to a picture of profound depression and mental disorder) are in agreement with data obtained in the Brazilian ${ }^{(9,16-18)}$ and international literature ${ }^{(21,32-33)}$. These data showed that suicidal ideation, planning, and attempted suicide correspond to the most relevant risk factors for consummation of suicide. Risk of suicide can be found in verbal communications, behaviors, situational cases and some sets of signals ${ }^{(19)}$. In the case of verbal manifestation, the elderly person can go straight to the subject and confide to people close to him his desire to die ${ }^{(19,21,32,34)}$. Regarding attitudes, they should be considered true warnings: carelessness and/or medication storage; make a will; self-negligence and access to lethal means, such as the acquisition of carbamate, popularly known as rodenticide, which, despite having prohibited sale, is still easily found ${ }^{(19-21)}$.

Mental disorder is the most intrinsic risk factor for risk of suicide in the elderly. A study in Europe ${ }^{(34)}$ reported that the prevalence of psychiatric illness in the elderly who died from suicide ranged from 71.4 to $96.5 \%$. Major depression is the most frequent psychiatric diagnosis in this population. There was a significant association between mood disorder and physical and terminal illnesses ${ }^{(34)}$. In Brazil, researchers estimated that more than $25.0 \%$ of the elderly population had clinically significant depressive symptoms and $7.0 \%$ had major depression ${ }^{(35)}$. A meta-analysis ${ }^{(36)}$ carried out found that the prevalence of depressive symptoms is even greater among elderly hospitalized in Brazil, with rates varying from $20.0 \%$ to $56.0 \%$.

\section{Study limitations}

It is considered as limitation of this study, the accomplishment of this research with a specific population - the elderly, limiting the results found only for this specific population. In this way, future studies are necessary for other populations in order to contribute to the knowledge and the discernment of the professional when judging the presence of ND to build an effective care plan. In addition, it is believed that a larger sample of experts would make the assessment of definitions more homogeneous.

\section{Contributions to Nursing, Health or Public Policy}

The definitions content of the factors for Risk of suicide in the elderly is accurately defined and validated from the point of view of experts. 
Thus, is fundamental that nurses use conceptual and operational definitions in the clinical judgment regarding identification of Risk of suicide in the elderly in order to make clinical practice more accurate.

\section{CONCLUSION}

The validation of risk factors for suicide in the elderly by expert nurses demonstrated that the conceptual and operational definitions of most of the risk factors addressed were considered clear, accurate, simple and relevant. The conceptual and operational definitions of retirement, chronic pain, vision problems and frustration factors have been adjusted, as recommended by the judges. It is suggested the exclusion of rigidity as a risk factor for Risk of suicide. Moreover, clinical validation of the risk factors validated in this study is necessary in order to identify the really relevant risk factors in care in the Brazilian setting.

\section{REFERENCES}

1. Durkheim E. O Suicídio. 3a ed. Lisboa: Editorial Presença; 1982.

2. World Health Organization (WHO). Preventing suicide: a global imperative [Internet]. Geneva: WHO; 2014. [cited 2017 Oct 17]. Available from: https://apps.who.int/iris/handle/10665/131056

3. Ministério da Saúde (MS). Ministério da Saúde lança Agenda Estratégica de Prevenção ao Suicídio [Internet]. Brasília: Ministério da Saúde; 2017 [cited 2017 Oct 17]. Available from: http://portalarquivos.saude.gov.br/images/pdf/2017/setembro/21/Coletiva-suicidio-21-09.pdf

4. World Health Organization (WHO). The World Health Report 2001. Mental Health: New Understanding, New Hope [Internet]. Geneva: WHO; 2002 [cited 2017 Oct 15]. Available from: www.who.int/whr/2001

5. American Association of Suicidology (AAS). U.S.A. Suicide: 2015 Official Final Data [Internet]. United States: AAS; 2016 [cited 2018 Jul 23$].$ Available from: http://www.suicidology.org/portals/14/docs/resources/factsheets/2015/2015datapgsv1.pdf?ver=2017-01-02-220151-870

6. Instituto Brasileiro de Geografia e Estatística (IBGE). Indicadores sociodemográficos e de saúde no Brasil - 2009 [Internet]. Rio de Janeiro: IBGE; 2009 [cited 2018 Jul 23]. Available from: https://ww2.ibge.gov.br/english/estatistica/populacao/indic_sociosaude/2009/indicsaude.pdf

7. Giacomin KC, Firmo JOA. Old age, disability and care in public health. Ciênc Saúde Colet. 2015;20(12):3631-40. doi: 10.1590/1413-812320152012.11752014

8. North American Nursing Diagnosis Association (NANDA). Diagnósticos de enfermagem da NANDA: definições e classificação $2015-2017$. Porto Alegre: Artmed; 2015.

9. Sousa GS, Perrelli JGA, Sougey EB. Nursing diagnosis for risk of suicide in elderly: integrative review. Rev Gaúcha Enferm. 2018;39:e20170120. doi: 10.1590/1983-1447.2018.2017-0120

10. Lopes MVO, Silva VM, Araújo TL. Methods for establishing the accuracy of clinical indicators in predicting nursing diagnoses. Int J Nurs Knowl. 2012;23(3):134-9. doi: 10.1111/j.2047-3095.2012.01213.x

11. O'Connor RC. Towards an integrated motivational-volitional model of suicidal behaviour. In: O'Connor RC, Platt S, Gordon J, editors. International Handbook of Suicide Prevention: Research, Policy and Practice. Hoboken: John Wiley \& Sons; 2011. p. 181-98.

12. Pasquali L. Instrumentação Psicológica: fundamentos e práticas. Porto Alegre: Artmed; 2009.

13. Dalmoro M, Vieira KM. Dilemas na construção de escalas Tipo Likert: o número de itens e a disposição influenciam nos resultados? Rev Gestão Org. 2013;6(3):161-74. doi: 10.22277/rgo.v6i3.1386

14. Fehring RJ. The Fehring model. In: Carroll-Johnson RR, Paquette M. Classification of nursing diagnoses: proceeding of the tenth conference. Philadelphia: Lippincott Company; 1994. p. 55-62.

15. Kjølseth I, Ekeberg Ø, Steihaug S. "Why do they become vulnerable when faced with the challenges of old age?" Elderly people who committed suicide, described by those who knew them. Int Psychogeriatr. 2009;21(5):903-12. doi: 10.1017/S104161020999034216

16. Silva RS, Mangas RMN, Figueiredo AEB, Vieira LJES, Sousa GS, Cavalcanti AMTS, et al. The influence of family problems and conflicts on suicidal ideation and suicide attempts in elderly people. Ciênc Saude Colet. 2015;20(6):1703-10. doi: 10.1590/1413-81232015206.01952015

17. Meneghel SN, Moura R, Hesler LZ, Gutierrez DMD. Tentativa de suicídio em mulheres idosas - uma perspectiva de gênero. Ciênc Saude Colet. 2015;20(6):1721-30. doi: 10.1590/1413-81232015206.02112015

18. Minayo MCS, Cavalcante FG. Qualitative study on suicide attempts and ideations with 60 elderly in Brazil. Ciênc Saúde Colet. 2015;20(6):1655-66. doi: 10.1590/1413-81232015206.06462015

19. Minayo MCS, Cavalcante FG. Suicide attempts among the elderly: a review of the literature (2002/2013). Ciênc Saúde Colet. 2015;20(6):1751-62. doi: 10.1590/1413-81232015206.10962014

20. Šedivya NZ, Podlogar T, Kerr DCR, De Leo D. Community social support as a protective factor against suicide: A genderspecific ecological study of 75 regions of 23 European countries. Health Place. 2017;48:40-6. doi: 10.1016/j.healthplace.2017.09.004

21. De Leo D, Draper BM, Snowdon J, Kõlves K. Suicides in older adults: a case-control psychological autopsy study in Australia. J Psychiatr Res. 2013;47(7):980-8. doi: 10.1016/j.jpsychires.2013.02.009

22. Rodrigues RAP, Monteiro EA, Santos AMR, Pontes MLF, Fhon JRS, Bolina AF, et. al. Older adults abuse in three Brazilian cities. Rev Bras Enferm. 2017;70(4):783-91. doi: 10.1590/0034-7167-2017-0114 
23. Conwell Y, Duberstein PR, Hirsch JK, Conner KR, Eberly S, Caine ED. Health status and suicide in the second half of life. Int J Geriatr Psychiatry. 2010;25(4):371-9. doi: 10.1002/gps.2348

24. Santos MA. Câncer e suicídio em idosos: determinantes psicossociais do risco, psicopatologia e oportunidades para prevenção. Ciênc Saúde Colet. 2017;22(9):3061-75. doi: 10.1590/1413-81232017229.05882016

25. Zhang XK, Procter NG, Xu Q, Chen XY, Lou FL. Factors influencing suicidal ideation among Chinese patients with stomach cancer: qualitative study. Int Nurs Rev. 2017;64(3):413-20. doi: 10.1111/inr.12344

26. Harrison KE, Dombrovski AY, Morse JQ, Houck P, Schlernitzauer M, Reynolds III CF, et. al. Alone? perceived social support and chronic interpersonal difficulties in suicidal elders. Int Psychogeriatr. 2010;22(3):445-54. doi: 10.1017/S1041610209991463.

27. van Heeringen K, Bijttebier S, Desmyter S, Vervaet M, Baeken C. Is there a neuroanatomical basis of the vulnerability to suicidal behavior? A coordinate-based meta-analysis of structural and functional MRI studies. Front Hum Neurosci. 2014;8:824. doi: 10.3389/fnhum.2014.00824

28. van Heeringen C, Bijttebier S, Godfrin K. Suicidal brains: a review of functional and structural brain studies in association with suicidal behaviour. Neurosci Biobehav Rev. 2011;3(5):688-98. doi: 10.1016/j.neubiorev.2010.08.007

29. Pollock LR, Williams JMG. Effective problem solving in suicide attempters depends on specific autobiographical recall. Suicide Life Threat Behav. 2001;31(4):386-96. doi: 10.1521/suli.31.4.386.22041

30. Miranda R, Valderrama J, Tsypes A, Gadol E, Gallagher M. Cognitive inflexibility and suicidal ideation: mediating role of brooding and hopelessness. Psychiatry Res. 2013;210(1):174-81. doi: 10.1016/j.psychres.2013.02.033

31. Nolen-Hoeksema S. The response style theory. In: Papageorgiou C, Wells A, editors. Rumination: nature, theory, and treatment of negative thinking in depression. Chichester: John Wiley \& Sons; 2004. p. 107-24.

32. Britton PC, Duberstein PR, Conner KR, Heisel MJ, Hirsch JK, Conwell Y. Reasons for living, hopelessness, and suicide ideation among depressed adults 50 years or older. Am J Geriatr Psychiatry. 2008;16(9):736-41. doi: 10.1097/JGP.0b013e31817b609a

33. Ministério da Saúde (MS). Prevenção do Suicídio: manual dirigido a profissionais das equipes de saúde mental [Internet]. Brasília: Ministério da Saúde; 2006 [cited 2017 Oct 17]. Available from: https://www.cvv.org.br/wp-content/uploads/2017/05/manual_prevencao_suicidio_ profissionais_saude.pdf

34. Vasiliadis HM, Lamoureaux-Lamarche C, Guerra SG. Gender and age group differences in suicide risk associated with co-morbid physical and psychiatric disorders in older adults. Int Psychogeriatr. 2017;29(2):249-57. doi: 10.1017/S1041610216001290

35. Barcelos-Ferreira R, Izbicki R, Steffens DC, Bottino CMC. Depressive morbidity and gender in community-dwelling Brazilian elderly: systematic review and meta-analysis. Int Psychogeriatr. 2010;22(5):712-26. doi: 10.1017/S1041610210000463

36. Castro-de-Araújo LFS, Barcelos-Ferreira R, Martins CB, Bottino CMC. Depressive morbidity among elderly individuals who are hospitalized, reside at long-term care facilities, and are under outpatient care in Brazil: a meta-analysis. Rev Bras Psiquiatr. 2013;35(2):201-7. doi: 10.1590/1516-4446-2012-0905 